\title{
The Influence of Self-Regulation towards Academic Achievement in English among Malaysian Upper Primary Students
}

\author{
Lo Sook Shing*, Mohd Rustam Mohd Rameli \\ Faculty of Social Sciences and Humanities, Universiti Teknologi Malaysia (UTM), Malaysia
}

Received January 22, 2020; Revised April 1, 2020; Accepted April 21, 2020

Copyright $\bigcirc 2020$ by authors, all rights reserved. Authors agree that this article remains permanently open access under the terms of the Creative Commons Attribution License 4.0 International License

\begin{abstract}
Negative feelings towards English language learning are a common for some students due to the time constraint and needed of more effort. The main objective of this study was to investigate the influence of self-regulation towards upper primary students' academic achievement in English in Johor Bahru. This study employs quantitative approach by using survey research design. The study was carried out to investigate the significant difference of self-regulation in learning English across gender and student achievement level. Instrument used in this study is Self-Regulated Learning Questionnaire. The respondents were 389 Primary 4 and Primary 5 students from the Chinese primary schools in Johor Bahru. The sampling technique used was simple random sampling. Based on the study, it showed no significant difference of self-regulation in learning English across gender during forethought phase $(\mathrm{t}=-.544, \mathrm{p}=.587)$. There is significant difference of self-regulation in learning English across gender during performance phase $(\mathrm{t}=-2.289, \mathrm{p}=.023)$ and self-reflective phase $(\mathrm{t}=-3.254, \mathrm{p}=.001)$. There is significant difference of self-regulation in learning English across student achievement level during forethought phase $(F=3.610, p$ $=.000)$, performance phase $(\mathrm{F}=1.761, \mathrm{p}=.001)$ and self-reflective phase $(\mathrm{F}=2.869, \mathrm{p}=.000)$. Regression analysis was performed to predict the influence of self-regulation towards upper primary students' academic achievement in English. Findings showed there is significant influence of self-regulation towards upper primary students' academic achievement in English during forethought and performance phase. The findings of the study provide instructional implications for teachers and English language learners, as well as to enrich the current empirical research data in Malaysia context.
\end{abstract}

Keywords Self-Regulation, Academic Achievement, Gender, Upper Primary Students

\section{Introduction}

Based on the education policy over the past decades, the students are taught the "3 R's" which are reading, writing and arithmetic in language and social studies [1]. However, the evident proves that knowledge alone is not enough to prepare students to thrive in the world. According to Paige [2], knowledge, thinking, innovation skills, media, and real life experience should be blended and adopted in $21^{\text {st }}$ century curriculum especially in the context of core academic subjects. A balanced education as its foundation is continued to be used as the National Education Philosophy's vision as stated in the Education Blueprint Malaysia 2013-2025. One of the student's aspiration include thinking skills which every child will have to learn how to continue gaining knowledge throughout their lives. Every child will have to master in cognitive skills such as critical thinking, reasoning, creative thinking and innovation so that love was instilled for inquiry and lifelong learning in the same time the different pieces of knowledge are to be connected hence to create new knowledge. However, students were found to be less competent in applying knowledge and thinking critically outside familiar academic contexts and thus the education system was historically fallen short in this area [1].

In recent years, self-regulated learning (SRL) has become important towards the students. With self-regulated learning attitude, students will realise their learning responsibilities on when and what extend to learn, knowing relevant methods and strategies related to the structuring of learning on their own. Self-regulation strategies are individual skills that the students have to develop in order to be successful in their lives since they are conceivable, learnable and controllable [3]. 
Self-regulation is not a personality trait which measures one's mental intelligence, instead it is learnt through experience [4,5]. To promote active engagement in learning among students, positive educational outcomes and desirable characteristics need to be linked with the importance of self-regulated learning as supported by previous studies [6-8].

As stated in The Education Blueprint 2013-2025, bilingual proficiency is one of the National Education Philosophy's vision that would need students to thrive in. In Malaysia, every child will be operationally proficient in Bahasa Malaysia and English as Bahasa Malaysia is the national language while English acts as the international language of communication. In other words, the students gain advantages in the workplace by being bilingualism upon leaving school [1]. Moreover, as encouraged by Malaysia government, English is considered to be an important second language to be learnt in order for the country to become developed and recognized internationally [9]. However, there is a decline in the standard of English in Malaysia since the students perceive it as a foreign language instead of second language. In the 2011 SPM English paper against Cambridge 1119 standards, only $28 \%$ of students achieved a minimum credit. Since 2006, Malaysia employers faced an issue which reported that most fresh graduates are poor in English proficiency. It has been ranked as one of the top five issues at that time [1].

Nowadays, it is believed that students will benefit most from curriculum that promotes active learning and independent thinking in view of the expectation of the competitive working force. Students are expected to perform more complex tasks in working tasks. However, the current education system does not adequately prepare students for success in life and career. A good self-regulator is the one who can withstand temptations, persist through obstacles, and delay gratification and are more likely to be physically healthier, more successful in their career, and experience more life satisfaction [10]. As such, it emphasizes on the importance of self-regulation.

\section{Problem Background}

In Malaysia, English is a second language to be learnt in primary schools and secondary schools. English learning is the center of significance due to the fact that it is the leading language of Science and Technology and emerged as the lingua franca in the world [11]. Most students do not have interest in learning English as it is just part of a subject for students to score in exam. The issue of improving the standard of English proficiency among young learners has been one of the most important topic in Malaysia. Due to the time constraint and more effort is needed, the students lose their interest and enthusiasm towards language learning most of the time. This also results in negative feelings such as low self-confidence and esteem [12], excessive anxiety [13], teacher's harsh and discouraging attitude and psychologically insecure classroom atmospheres [14].

There is a need for learners to develop a positive attitude towards English language learning for a better learning of English. In this regard, the factors of motivation were investigated by numerous researchers to further improve the learning of the target language [15,16]. In fact, motivation is the most influential factor that affects success of the language learner in the field of second language learning as shown in the studies. To improve the proficiency of English among students, the LINUS programme which consists of English literacy was promoted. To determine if the students who are in Year 1 to 3 are progressing in Bahasa Malaysia and English literacy at an expected pace, each of them will be screened twice a year. Remedial coaching will be given for those students who fall behind until they are able to catch up. According to international standards, every student will be taught English by a teacher who is proficient. This will be achieved by having all 61,000 English teachers to pass the Cambridge Placement Test (CPT) within two years. Teachers who have yet to meet this standard will receive intensive upskilling [1]. Furthermore, the performance targets for its performance on the PISA and TIMSS international assessments are also set and monitored by Ministry.

As supported by Juliana Othman [17], learning English should be fun and pupil-centred. According to the Malaysian primary school curriculum, learner-centred and activity-oriented teaching-learning strategies are promoted to ensure pupils gain basic linguistic knowledge in English. Based on the philosophy that the student is at the heart of the learning process, student-centred learning is implemented with the integration of innovative teaching, team learning, problem-based learning, and self-regulated learning [18]. Today, education system is built to standardize the way we teach and test. Strengthening education system and focusing on children's learning is a key to improve global education. However, student's learning outcome is based on their result and academic performance. The quality of children's lives before beginning formal education greatly influences the kind of learners they can be. These include their early childhood experiences, home support and health [19].

Self-regulation is a key ingredient in learning performance as shown in a large number of studies [20,21]. The basic components of self-regulation, from the operant perspective are goal setting, self-instruction, self-monitoring and self-reinforcement. Recent educational researches show that self-regulated learning helps students to achieve the adaptiveness to the school environment in order to reach the learning outcome [21]. Self-regulated process requires students to independently plan, monitor and assess their learning in the same time acts as an 
important predictor of student academic motivation and achievement. However, few students naturally do this well [22]. Self-regulation is important in the learning process. With self-regulation, students create better learning habits and therefore their study skills are strengthen.-

There was a dramatic change in the Malaysia education system when the Smart School Project was implemented in 1999. Under this Smart School Project, the learning concepts focus on student-centred learning, active knowledge construction, as well as critical and creative thinking. Smart schools refer to schools that have internet for all students and take advantage of the latest technologies in teaching and school management [23]. It focuses on student-centred learning such as to develop students' active knowledge as well as creative and critical thinking which is a big difference compared with the conventional pedagogy. In other words, without relying too much on teachers, students have to be self-initiate, self-direct, self-access and self-pace in learning.

Gender differences in self-regulatory abilities among children have been discovered by many researchers whereby girls displaying higher level of self-regulation at an earlier age than boys $[24,25]$. As reported by Hartley and Sutton [26], boys develop gender stereotypes as to which girls are perceived as academically superior in terms of motivation, self-regulation and performance. However, some of the studies revealed inconsistent results in which gender differences in academic achievement depend on different domains of school achievement [27]. In terms of achievement motivation, females tend to be doing well in school by engaging themselves in classroom activities [28]. Females prefer tasks where they know they can succeed, while males prefer tasks which embrace more challenges [29]. For the positive relationship between greater school achievement and self-regulation by girls, it is supported by Duckworth and Seligman [30] that in a sample of US-American eighth graders, girls' higher school achievement can be explained by behaviour regulation, which is a part of the component of self-regulation.

In Malaysia, there are hardly any documented records of studies of learning about students' use of self-regulated learning in the specific domain [31]. The past studies are limited to show the relationship between self-regulation and academic achievement in English in Malaysia context. In education literature, the concept of low achievement (failure to meet average academic performance) is different from underachievement (a discrepancy between ability and expected performance) [32]. According to Pintrich, Smith, Gracia and McKeachie [33], a high achiever students had used more SRL compared to low achiever students. Self-regulation abilities can predict individuals' health problems, socioeconomic position, and tendency to criminal offence [34]. One must have both intrinsic and extrinsic motivation consistent with the goal of achieving behaviour for a certain period in order to achieve successful self-regulation. According to Zenner,
Herrnleben-Kurz and Walach [35], self-regulation abilities facilitate goal oriented actions and optimal adjusting to emotional and cognitive challenging stimulating throughout successful regulation of feelings, emotions, behaviours, and cognitions.

\section{Research Objectives}

The objectives of this research are as following:

i. To examine the difference of self-regulation in learning English across gender.

ii. To examine the difference of self-regulation in learning English across student achievement level.

iii. To investigate the influence of self-regulation towards upper primary students' academic achievement in English.

\section{Methodology}

This research study was carried out in Chinese primary schools in Johor Bahru district of Johor state, Malaysia. Simple random sampling has been applied to determine the population samples. 389 students of Primary 4 and Primary 5 from the Chinese primary schools in Johor Bahru district had been randomly selected as the samples of the study.

In this study, primary data is collected from the questionnaire distributed among the upper primary students. Instrument used to measure self-regulation level in English among upper primary students is Self-Regulated Learning Questionnaire [36]. This instrument was chosen because it involves the three phases of self-regulation. In addition, this instrument is based on triadic model of self-regulation theory by Bandura [37]. All the items in this instrument are categorised into three phases to answer the research questions. Research done by Wu showed that each construct in this instrument has the high reliability which is more than 0.7 [38]. To customize the items in research context, each of the item was modified to be specialised for English.

The questionnaire consists of 2 sections. Section $\mathrm{A}$ is the demographic data while section B consists of the scaling items that need respondents to assess it. The main purpose of section A is to get some background information of the respondents. The demographic variables include student's gender, ethnic, age, and the mid term score for Paper 2 in English. For section B, it consists of 40 items which is designed to assess student's motivation and self-regulation in learning English in class. The questions are set in rating scales with four options which include 'strongly agree', 'agree', 'disagree' and 'strongly disagree' whereby it is very useful to build in a degree of sensitivity and differentiation of response. Ethical procedures include informed consent, confidentiality and anonymity were followed while conducting this research. 
Table 1. Statistic Tests of Self-regulation across Gender during Three Phases

\begin{tabular}{|c|c|c|c|c|c|c|c|c|c|}
\hline & Gender & $\mathrm{N}$ & Mean & $\begin{array}{c}\text { Std. } \\
\text { Dev. }\end{array}$ & $\mathrm{F}$ & Sig. & $\mathrm{t}$ & $\mathrm{df}$ & $\begin{array}{c}\text { Sig. } \\
\text { (2-tailed) }\end{array}$ \\
\hline \multirow{3}{*}{ Forethought } & MALE & 211 & 2.82 & .60 & 4.921 & .027 & -.544 & 387 & .587 \\
\cline { 2 - 12 } & FEMALE & 178 & 2.85 & .49 & & & -.554 & 386.303 & .580 \\
\hline \multirow{3}{*}{ Performance } & MALE & 211 & 2.54 & .78 & 9.376 & .002 & -2.289 & 387 & .023 \\
\cline { 2 - 12 } & FEMALE & 178 & 2.71 & .65 & & & -2.324 & 386.978 & .021 \\
\hline \multirow{2}{*}{ Self-Reflective } & MALE & 211 & 2.66 & .52 & 4.732 & .030 & -3.254 & 387 & .001 \\
\cline { 2 - 12 } & FEMALE & 178 & 2.82 & .44 & & & -3.298 & 386.950 & .001 \\
\hline
\end{tabular}

\section{Findings}

Table 1 showed the statistic tests of self-regulation across gender during three phases. During forethought phase, the mean value of the male students is 2.82 whereas the mean value is 2.85 for the female which is slightly higher as compared with male. Result indicated that during forethought phase, the significant value is .587 which is greater than the alpha value, .05 , which it is failed to reject null hypothesis. This means that there is no significant difference of self-regulation in learning English across gender during forethought phase.

During performance phase, the mean value of self-regulation of female is higher which is 2.71 compared with the mean value of self-regulation among male which is 2.54 . The significant value is .023 which is smaller than the alpha value, .05 and thus null hypothesis was rejected. This means that there is significant difference of self-regulation in learning English across gender during performance phase.

During self-reflective phase, the mean value of the male students is 2.66 whereas the mean value is 2.82 for the female which is higher as compared with male. The significant value is .001 which is smaller than the alpha value, .05 . The result indicated that null hypothesis was rejected. On the other hand, this means that there is significant difference of self-regulation in learning English across gender during self-reflective phase.

Table 2 represented the Anova tests of self-regulation and student achievement level during three phases. During forethought phase, the significant value as shown in the table is .000 which is smaller than the alpha value, .05 . The result indicated that null hypothesis was rejected. Therefore, there is significant difference of self-regulation in learning English across student achievement level during forethought phase. During performance phase, the significant value as shown in the table is .001 which is smaller than the alpha value, .05 . The result indicated that null hypothesis was rejected. Therefore, there is significant difference of self-regulation in learning English across student achievement level during performance phase. During self-reflective phase, the significant value as shown in the table is .000 which is smaller than the alpha value, .05 . The result indicated that null hypothesis was rejected. Therefore, there is significant difference of self-regulation in learning English across student achievement level during self-reflective phase. 
Table 2. Anova Tests of Self-Regulation and Student Achievement Level during Three Phases

\begin{tabular}{|c|c|c|c|c|c|c|}
\hline & & $\begin{array}{l}\text { Sum of } \\
\text { Squares }\end{array}$ & Df & Mean Square & $\mathrm{F}$ & Sig. \\
\hline \multirow{3}{*}{ Forethought } & Between Groups & 48.107 & 62 & .776 & 3.610 & .000 \\
\hline & Within Groups & 70.073 & 326 & .215 & & \\
\hline & Total & 118.179 & 388 & & & \\
\hline \multirow{3}{*}{ Performance } & Between Groups & 51.499 & 62 & .831 & 1.761 & .001 \\
\hline & Within Groups & 153.812 & 326 & .472 & & \\
\hline & Total & 205.312 & 388 & & & \\
\hline \multirow{3}{*}{ Self-Reflective } & Between Groups & 32.785 & 62 & .529 & 2.869 & .000 \\
\hline & Within Groups & 60.086 & 326 & .184 & & \\
\hline & Total & 92.871 & 388 & & & \\
\hline
\end{tabular}

Table 3. Post-Hoc Test of Categorisation of Achiever for Three Phases

\begin{tabular}{|c|c|c|c|c|}
\hline Dependent Variable & $\begin{array}{c}\text { Categorisation of } \\
\text { Achiever }\end{array}$ & Categorisation of Achiever & Std. Error & Sig. \\
\hline \multirow{6}{*}{ Forethought } & \multirow{2}{*}{ Low } & Moderate & .07447 & .012 \\
\hline & & High & .06203 & .000 \\
\hline & \multirow{2}{*}{ Moderate } & Low & .07447 & .012 \\
\hline & & High & .08263 & .091 \\
\hline & \multirow{2}{*}{ High } & Low & .06203 & .000 \\
\hline & & Moderate & .08263 & .091 \\
\hline \multirow{6}{*}{ Performance } & \multirow{2}{*}{ Low } & Moderate & .10249 & .135 \\
\hline & & High & .08538 & .200 \\
\hline & \multirow{2}{*}{ Moderate } & Low & .10249 & .135 \\
\hline & & High & .11373 & .899 \\
\hline & \multirow{2}{*}{ High } & Low & .08538 & .200 \\
\hline & & Moderate & .11373 & .899 \\
\hline \multirow{6}{*}{ Self-Reflective } & \multirow{2}{*}{ Low } & Moderate & .06695 & .664 \\
\hline & & High & .05577 & .000 \\
\hline & \multirow{2}{*}{ Moderate } & Low & .06695 & .664 \\
\hline & & High & .07429 & .004 \\
\hline & \multirow{2}{*}{ High } & Low & .05577 & .000 \\
\hline & & Moderate & .07429 & .004 \\
\hline
\end{tabular}

Table 3 showed the post-hoc test of categorisation of achiever based on three phases of self-regulation. Post-hoc test was done where null hypothesis is rejected with more than two treatment conditions. On the other hand, it was designed to explore the differences among means to provide specific information on which means are significantly different from each other. During forethought phase, the significant value between low achiever and moderate achiever is .012 while the significant value showed .000 between low achiever and high achiever. This showed that null hypothesis was rejected. Therefore, there was significant difference of self-regulation in learning English between low achiever and moderate achiever, in the same time between low achiever and high achiever during forethought phase.

During performance phase, all the significant values are greater than the alpha value, .05 and thus it is failed to reject null hypothesis and there was no significant difference of self-regulation across student achievement level during performance phase. During self-reflective phase, the significant value between low achiever and high achiever is .000 while the significant value showed .004 between moderate achiever and high achiever. This showed that null hypothesis was rejected. Therefore, there was significant difference of self-regulation in learning English between low achiever and high achiever, in the same time between moderate achiever and high achiever during self-reflective phase.

Table 4 showed the regression value between self-regulation and academic achievement among upper primary students. With the overall mean of self-regulation level, $12.2 \%$ of self-regulation accounted for student academic achievement. 
Table 4. Regression Value between Self-regulation and Academic Achievement

\begin{tabular}{|c|c|c|c|c|}
\hline Model & $\mathrm{R}$ & $\mathrm{R}$ Square & Adjusted R Square & Std. Error of the Estimate \\
\hline 1 & $.349^{\mathrm{a}}$ & .122 & .120 & 19.347 \\
\hline
\end{tabular}

As shown in table 5, with 'Forethought' alone, self-regulation contributes $16.7 \%$ of the changes of the variance towards academic achievement. With both 'Forethought' and 'Performance', self-regulation contributes $17.6 \%$ of the changes of the variance towards academic achievement.

Table 5. Regression Value between Self-regulation and Academic Achievement for Different Phases

\begin{tabular}{|c|c|c|c|c|}
\hline Model & $\mathrm{R}$ & $\mathrm{R}$ Square & Adjusted R Square & Std. Error of the Estimate \\
\hline 1 & $.411^{\mathrm{a}}$ & .169 & .167 & 18.818 \\
\hline 2 & $.425^{\mathrm{b}}$ & .180 & .176 & 18.717 \\
\hline
\end{tabular}

Table 6 showed the regression test between the influence of self-regulation and student's academic achievement in English. The significant value is .000 which is smaller than the alpha value, .05 and thus null hypothesis was rejected. This means that there is significant influence of self-regulation towards upper primary students' academic achievement in English during forethought phase. Furthermore, the result as shown in table 6 also presented that during phase of forethought and performance, the significant value is .000 which means null hypothesis was rejected. Thus, there is significant influence of self-regulation towards upper primary students' academic achievement in English during forethought and performance phase.

Table 6. Statistical Test between Self-regulation and Academic Achievement

\begin{tabular}{|c|c|c|c|c|c|c|}
\hline \multicolumn{2}{|c|}{ Model } & Sum of Squares & df & Mean Square & F & Sig. \\
\hline \multirow{3}{*}{1} & Regression & 27935.717 & 1 & 27935.717 & 78.888 & $.000^{\text {b }}$ \\
\cline { 2 - 7 } & Residual & 137043.260 & 387 & 354.117 & & \\
\cline { 2 - 7 } & Total & 164978.977 & 388 & & & \\
\hline \multirow{2}{*}{2} & Regression & 29759.615 & 2 & 14879.807 & & $.000^{\text {c }}$ \\
\cline { 2 - 7 } & Residual & 135219.362 & 386 & 350.309 & & \\
\cline { 2 - 7 } & Total & 164978.977 & 388 & & & \\
\hline
\end{tabular}




\section{Discussion}

\subsection{Discussion on Self-regulation in Learning English across Gender}

During the three phases of self-regulation, all the mean values of self-regulation among female students are higher than male students. This indicated that female students are more self-regulated than males in learning. This is supported by few of the studies that self-regulation proved to be connected to gender $[39,40]$. As compared with males, females are generally report more intensive use of self-regulatory strategies than men [39].

The findings showed that there is no significant difference of self-regulation in learning English across gender during forethought phase. As supported by Bembenutty [41], his study did not reveal differences between females and males in terms of the usage of learning material and effort management. As far as there is concern about the gender differences in metacognitive self-regulation, inconsistent research results were obtained [41]. Despite the inconsistent results obtained across gender, one of the major ways in which gender influences learning and performance is through the differing self-efficacy beliefs held by males and females for academic tasks and self-regulated learning. From the early school years, gender differences in self-efficacy beliefs are apparent. Girls from age 10 to 12 typically achieve higher science grades than do boys. However, Britner and Pajares [42] found that girls' success at Science was not matched by higher science self-efficacy beliefs than boys. This mismatch between self-efficacy beliefs and performance is likely, over time, to negatively impact on girls' achievement in science. This is one of the reason to support the findings in this study that result showed no significant difference of self-regulation in learning English across gender during forethought phase.

Consistent with the view of self-efficacy beliefs and performance, Pajares and Miller [43] have shown that self-efficacy for solving math problem was highly predictive of math achievement. Self-efficacy beliefs are important for future achievement as the more students believe they are capable of mastering a particular activity the more effort they expend in learning about it and the more persevere when they encounter difficulties. The more confident students are about their capabilities, the less performances are likely to be undermined by anxiety [44].

During performance phase, the findings showed that there is significant difference of self-regulation in learning English across gender. As discussed earlier, two processes which include self-observation and self-control are important to determine one's self-regulation. With the systematic monitoring of one's performance, regulating one's behaviour is part of self-observation. For example, a language learner will try to understand the part of the English lesson which he/she does not understand after completion of each topic. When it comes to self-observation, females tend to be doing well than males in school and they are more engaged in classroom activities [28].

In term of the aspect of self-control, the imagery strategy helps one to visualize and enhance memorization by organizing information in a systematic way. On the other hand, the self-instruction strategy helps one to monitor and control the focus level through verbalizations. This is supported by a study conducted by Edens [45] which his findings revealed that females show slightly higher verbal ability while males show slightly higher visual-spatial ability [45]. Finding indicates that applying visualisation and verbalisation techniques has boosted the language learner's vocabulary knowledge [46]. Hence, there is significant difference of self-regulation across gender during performance phase.

Furthermore, the findings showed that there is significant difference of self-regulation in learning English across gender during self-reflective phase. In view of the importance of self-satisfaction, females prefer tasks which they are more confident to gain success, while males are more willing to take academic challenges [29]. Females, unlike males, tend to attribute failure to a lack of ability while males, tend to take their failures in stride, attributing them to a lack of effort [29]. With regard to adaptivity, women are more effort goals oriented than men [47] and more frequently adapt effort to task requirements [48].

\subsection{Discussion on Self-regulation in Learning English across Student Achievement Level}

There is significant difference of self-regulation in learning English across student achievement level during three phases, which are forethought phase, performance phase and self-reflective phase. Student achievement level is divided into three components that include low, moderate and high. Like other forms of academic achievement, achievement in language learning depends on expertise in self-regulatory processes. A person who is self-regulated will have his/her own responsibility in learning to organize himself/herself, formulate goals and anticipate problems to achieve in a better way which he/she aims for. Those who are self-regulated will get to use the easy learning style which suits their talents and interests [10]. Self-regulated learning can be related with better academic performance. For example, high achieving students using its defining strategies more frequently and effectively than their lower achieving peers $[49,50]$.

During forethought phase, one of the important aspect includes self-efficacy which is part of learning motivation. Ahmed [51] presented that there is significant difference in self-efficacy among the high and low achieving undergraduates at Al-Hussein Bin Talal University in Jordan. The past researches revealed that there is significant positive relationship between self-efficacy and 
academic achievement among the undergraduates and pre-service teachers. In view of this, it indicated that part of the learning construct in self-regulation for forethought phase shows difference among low and high achiever and this is supported by the findings from this study based on post-hoc test.

Two components to be focused during performance phase is self-observation and self-control. Self-observation is important for students to realize if the comprehension of the material falls short of a learning goal and thus related adjustments are to be made to their future learning processes [52]. Furthermore, it enables the students to control their progress towards the achievement of their learning goal. On the other hand, self-control is important for the students to take the needed steps in improving their learning such as the ability to organize themselves in a timely manner and hence persevere to reach them [53,54]. As supported by past studies, high achieving students are more self-regulated in taking initiative and are voluntarily in seeking for learning material and strategy compared to low achieving students.

As reported by Zimmerman [55], self-reflective phase is associated with forethought processes in term of the impact of decisions one makes. The goals that one sets could affect his/her motivation either it is a quality one or vice versa. Quality goals will motivate one in planning and organizing goal-relevant tasks, stimulate greater persistence over time and influence students to put in more effort by generating greater self-satisfaction [56]. Without having a proper planning of goal-relevant tasks, a study conducted by Mohd Shah [57] among the Malaysian university showed that the students' low achievement in second language is due to their lack of language learning strategies which direct will pave the way toward one's self-regulation. Quality and good learning strategy is a better lead to self-regulation and this is an important learning construct for moderate and high achieving language learners as effective self-regulators will engage themselves in skilful strategy during learning [58].

\subsection{Discussion on the Influence of Self-regulation towards Upper Primary Students' Academic Achievement in English}

The findings showed that there is significant influence of self-regulation towards upper primary students' academic achievement in English during forethought and performance phase. Some empirical studies show that self-regulated learning is an essential stimulus to academic achievement [59-61]. Self-regulated learning encompasses many strongest predictors of achievement from planning to the execution and persisting of an academic task. It marks a shift in educational research with regards to students' learning capabilities and students' learning processes and responses which influence the students' academic success. In Egypt, a study conducted by Ahmad [62] on a sample of 128 students from the faculty of education revealed positive relationships between self-regulation and students' academic achievement.

As discussed, the influence of self-regulation towards upper primary students' academic achievement in English during forethought phase is significant. The main construct of self-regulation for forethought phase is learning motivation which refers to the student's willingness in studying. Effective self-regulated learners have a high degree of internal motivation. They have a greater readiness to exert the needed efforts and persevere for long periods of time [63]. A study conducted by Azlina [64] also indicated that self-efficacy is one of the significant predictors for academic achievement since it is one of the most influential factors for second language learning.

In addition, Al-Jarrah [65] conducted a study to examine the predictability of self-regulated learning (SRL) and academic achievement. In the same time, it investigated whether there is academic achievement difference among students with high or low levels of SRL. Purdie, Hattie, Douglas's [66] SRL scale was used on a sample of 331 male and female undergraduate students from Yarmouk University. His study revealed that there were statistically significant differences in academic achievement between students with high or low scores on the SRL in view of goal setting and planning, rehearsing and memorizing in the favour of the high self-regulated students.

\section{Conclusions}

This study emphasized on the influence of self-regulation towards upper primary students' academic achievement in English. Based on the findings of the study, all the mean values of self-regulation among female students are higher than male students during the three phases of self-regulation. It showed no significant difference of self-regulation in learning English across gender during forethought phase. This is because as far as gender differences in metacognitive self-regulation are concerned, inconsistent research results were obtained. However, there is significant difference of self-regulation in learning English across gender during performance and self-reflective phase. Most of the past studies also revealed positive relationships between self-regulation and students' academic achievement.

\section{Acknowledgements}

This study was supported by a grant from Fundamental Research Grant Scheme (Vot. No. RJI30000.7853.5F039). Opinions, findings and conclusions or recommendations expressed in the material are those of the authors and do not necessarily reflect those of the Malaysia Ministry of 
Education.

\section{REFERENCES}

[1] Ministry of Education Malaysia. (2016). Malaysia Education Blueprint 2013-2025. http://www.moe.gov.my/c $\mathrm{ms} /$ upload_files/articlefile/2013/articlefile_file_0031114.p df

[2] Paige, J. (2009). The 21st century skills movement. Educational Leadership, 9(67), 11-12.

[3] Denat, Y., Dikmen, Y., Arslan, G., Karalar, D., \& Yilmaz, G. (2017). Factors affecting self-regulated learning in nursing students in Turkey. Oxidation Communications, 40(2), 973-985.

[4] AemeroAsmamawChalachew. (2018). Factors and influence of self-regulation learning among sport science undergraduate students in Ethiopian universities. Research Journal of Social Sciences and Management, 8(7), 72-82.

[5] Xiao, S., Yao, K., \& Wang, T. (2019). The relationships of self-regulated learning and academic achievement in university students. EDP Sciences, 60, 1-4. doi: $10.1051 /$ shsconf/20196001003.

[6] Lai, C., \& Gu, M. (2011). Self-regulated out-of-class language learning with technology. Computer Assisted Language Learning, 24(4), 317-335. doi: $10.1080 / 09588221.2011 .568417$

[7] Nota, L., Soresi, S., \& Zimmerman, B. J. (2004). Self-regulation and academic achievement and resilience: A longitudinal study. International Journal of Educational Research, 41(3), 198-215. doi: 10.1016/j.ijer.2005.07.001

[8] Whipp, J. L., \& Chiarelli, S. (2004). Self-regulation in a web-based course: A case study. Educational Technology Research and Development, 52(4), 5-22.

[9] Abdul Kahrim, M. R. (1991). Malaysia Kita. Kuala Lumpur, Malaysia: Percetakan National Malaysia Berhad.

[10] Fauzi, A., \& Widjajanti, D. B. (2018). Self-regulated learning: The effect on student's mathematics achievement. Journal of Physics, 1097, 1-7. doi: 10.1088/1742-6596/1097/1/012139.

[11] Paramjit, K. (2014). Attitudes towards English as a lingua franca. Social and Behavioural Sciences, 118, 214-221.

[12] Normazidah Che Musa. (2012). Exploring English language learning and teaching in Malaysia. Journal of Language Studies, 12(1), 35-51.

[13] [13] Law, M. Y., \& Norlizah Che Hassan. (2015). Self-efficacy, learning strategies, and academic achievement among Malaysian future educators. Jurnal Pemikir Pendidikan, 6, 31-48.

[14] Maheen Sher Ali \& Zahid Hussain Pathan. (2016). Exploring factors causing demotivation and motivation in learning English language among college students of Quetta, Pakistan. International Journal of English Linguistics, 7(2), 81-89.
[15] Randi, J., \& Corno, L. (2000). Teacher innovations in self-regulated learning. In M. B Boekaerts, P. R. Pintrich \& M. Zeidner (Eds.), Handbook of self-regulation. San Diego: Academic Press.

[16] Pintrich, P. R. (2004). A conceptual framework for assessing motivation and self-regulatedlearning in college students. Educational Psychology Review, 16(4), 385-407.

[17] Juliana Othman. (2010). Teachers' instructional practices in teaching English at Malaysian primary schools. Proceedings of EDULEARN10 Conference, 483-491.

[18] Suriati binti Salleh, \& Nurahimah Mohd. Yusoff. (2016). Teachers' attitudes and beliefs towards the use of student-centred learning in English language classes. Proceedings of ICECRS1 Conference, 327-334.

[19] Bronson, M. B. (2000). Self-regulation in early childhood, nature and nurture. New York: Guilford Press.

[20] McClelland, M, M., \& Cameron, C. E. (2011). Self-regulation and academic achievement in elementary school children. New Directions for child and Adolescent Development, 133, 29-44.

[21] Daniela, P. (2015). The relationship between self-regulation, motivation and performance at secondary school students. Social and Behavioural Sciences, 191, 2549-2553.

[22] Berg, G. V. D., \& Coetzee, L. R. (2014). Academic self-concept and motivation as predictors of academic achievement. International Journal of Education Science, 6(3), 469-478.

[23] Ali Mohammad Naemi, \& Amin Naemi. (2017). Effectiveness of smart training on self-efficacy and self-regulation in Science course of fifth grade students of primary schools. International Journal of Educational and Psychological Researches, 3(1), 46-52.

[24] Weinberg, M., Tronick, E. Z., Cohn, J. F., \& Olson, K. L. (1999). Gender differences in emotional expressivity and self-regulation during early infancy. Developmental Psychology, 35(1), 175-188. doi:10.1037/0012-1649.35.1. 175

[25] Weis, M., Heikamp, T., \& Trommsdorff, G. (2013). Gender differences in school achievement: The role of self-regulation. Frontiers in Psychology, 4, 1-10. doi: 10.3389/fpsyg.2013.00442

[26] Hartley, B. L. \& Sutton, R. M. (2013). A stereotype threat account of boys' academic underachievement. Child Dev. Advance online publication. doi: 10.1111/ cdev.12079

[27] Schrader, F. \& Helmke, A. (2008). "Determinanten der Schulleistung [Determinants of school performance]," in LehrerSchüler-Interaktion. Inhaltsfelder, Forschungsperspektiven und methodische Zugänge, 2nd Edn. ed M. K. W. Schweer (Wiesbaden: Verlag für Sozialwissenshaften), 285-302. doi: 10.1007/978-3-53191104-5 11

[28] Binns, K., Steinberg, A., Amorosi, S., \& Cuevas, A. M. (1997). The Metropolitan Life survey of the American teacher 1997: Examining gender issues in public schools. NY: Louis Harris and Associates.

[29] Dweck, C. S. (2000). Self-theories: Their role in motivation, personality, and development. Philadelphia, PA: 
Psychology Press.

[30] Duckworth, A., and Seligman, M. (2006). Self-discipline gives girls the edge: gender in self-discipline, grades, and achievement test scores. J. Edu. Psychol. 98, 198-208. doi: 10.1037/0022-0663.98.1.198

[31] Marzita Puteh, \& Mahani Ibrahim. (2010). The usage of self-regulated learning strategies among Form four students in the Mathematical problem-solving context: A case study. Procedia Social and Behavioural Sciences, 8, 446-452.

[32] Wang, L. Y., Teng, S. S., \& Tan, C. S. (2014). Levelling up academically low progress students. National Institute of Education: Nanyang Technological University.

[33] Pintrich, P. R., Smith, D. A., Gracia, T., and McKeachie, W. J. (1991). A Manual for the Use of the Motivational Strategies for Learning Questionnaire (MSLQ). University of Michigan: National Centre for Research to Improve Postsecondary Teaching and Learning.

[34] Kaunhoven, R. J., \& Dorjee, D. (2017). How does mindfulness modulate self-regulation in pre-adolescent children? An integrative neurocognitive review. Neuroscience Biobehavioural, 74, 163-184.

[35] Zenner, C., Herrnleben-Kurz, S., \& Walach, H. (2014). Mindfulness-based interventions in schools-A systematic review and meta-analysis. Front Psychology, 5, 1-20.

[36] Wu, P. H. (2005). Examining the effects of self-regulated learning on junior high school students' academic performance using structural equation modelling. Unpublished Master's thesis. National Taiwan University of Science and Technology: Taipei.

[37] Bandura, A. (1986). Social foundations of thought and action: A social cognitive theory. Englewood Cliffs, NJ: Prentice-Hall.

[38] Nunnally, J. C. (1978) Psychometric theory. 2nd Edition, McGraw-Hill, New York.

[39] Studenska, A. (2011). Educational level, gender and foreign language learning self-regulation difficulty. Social and Behavioural Sciences, 29, 1349-1358.

[40] McCabe, L. A., Cunnington, M., \& Brooks-Gunn, J. (2007). The development of self-regulation in young children. In R. Baumeister, \& K. D. Vohs (Eds.), Handbook of self-regulation: Research, theory and applications (pp. 340-356). New York, London: The Guilford Press.

[41] Bembenutty, H. (2007). Self-regulation of learning and academic delay of gratification: Gender and ethnic differences among college students. Journal of Advanced Academics, 18(4), 586-616.

[42] Britner, S. L., \& Pajares, F. (2001). Self-efficacy beliefs, motivation, race, and gender in middle school science. Journal of Women and Minorities in Science and Engineering, 7, 271-285.

[43] Pajares, F., \& Miller, D. (1994). Role of self-efficacy and self-concept beliefs in Mathematical problem solving: A path analysis. Journal of Educational Psychology, 86, 193-203.

[44] Bandura, A. (1997). Self-efficacy: The exercise of control. New York: Freeman.
[45] Edens, K. M. (2006). The interaction of pedagogical approach, gender, self-regulation, and goal orientation using student response system technology. Journal of Research on Technology in Education, 41(2), 161-177.

[46] Ghaedi, R \& Shahrokhi, M. (2016). The impact of visualization and verbalization techniques on vocabulary learning of Iranian high school EFL learners: A gender perspective. Elsevier, 3, 32-42.

[47] Tang, M., \& Neber, H. (2008). Motivation and self-regulated science learning in high-achieving students: differences related to nation, gender, and grade level. High ability studies, 19(2), 103-116.

[48] Dresel, M., \& Haugwitz, M. (2005). The relationship between cognitive abilities and self-regulated learning: Evidence for interactions with academic self-concept and gender. High Ability Studies, 16(2), 201-218.

[49] Zimmerman, B. J. (1989). A social cognitive view of self-regulated academic learning. Journal of Educational Psychology, 81(3), 329-339. doi:10.1037/0022-0663.81.3. 329

[50] Zimmerman, B. J. (2002). Becoming a self-regulated learner: An overview. Theory into Practice, 41, 64-142.

[51] Ahmed Falah Al-Alwan. (2008). Self-regulated learning in high and low achieving students at Al-Hussein Bin Talal University (AHU) in Jordan. International Journal of Applied Educational Studies, 1(1). Retrieved June 17, 2011, from EBSCOhost database.

[52] Bembenutty, H. (2005). Academic achievement in a national sample: The contribution of self-regulation and motivational beliefs beyond and above parental involvement. Paper presented at the annual meeting of the American Educational Research Association, April 2005, Montreal, Canada.

[53] Garcia, T., \& Pintrich, P. R. (1994). Regulating motivation and cognition in the classroom: the role of selfschemas and self-regulatory processes. In D. H. Schunk \& B. J. Zimmerman (Eds.), Self-regulation of learning and performance: Issues and educational applications. Hillsdale: Erlbaum.

[54] Pintrich, P. R. (2000). The role of goal orientation in self-regulated learning. In: M. Boekaerts, P. R. Pintrich, M. Zeidner (eds.). Handbook of Self-regulation. San Diego: Academic Press.

[55] Zimmerman, B. J. (2000). Attaining self-regulation: A social cognitive perspective. In M. Boekaerts, P. R. Pintrich \& M. Zeidner (Eds.), Handbook of self-regulation (pp.13-39). San Diego, CA: Academic Press.

[56] Zimmerman, B. J. (2008a). Goal setting: A key proactive source of academic self- regulation. In D. H. Schunk \& B. J. Zimmerman (Eds.), Motivation and self- regulated learning: Theory, research, and applications. New York: Lawrence Erlbaum.

[57] Mohd Shah, P. (2002). Attitude, motivation, and individual characteristics as variables of $\mathrm{L} 2$ acquisition. In $\mathrm{M}$. Jayakaran, A. S. Arshad \& S. Teh (Eds.), Readings in English Language teaching (pp. 116-123). Serdang: University Putra Malaysia.

[58] Dörnyei, Z. (2005). The psychology of the language learner: 
Individual differences in second language acquisition. New Jersey: Lawrence Erlbaum.

[59] Zimmerman, B. J. (2008). Investigating self-regulation and motivation: Historical background, methodological developments, and future prospects. American Educational Research Journal, 45(1), 166-183. doi: $10.3102 / 0002831207312909$.

[60] Rakes, G. C., \& Dunn, K. E. (2010). The impact of online graduate students' motivation and self-regulation on academic procrastination. Journal of Interactive Online Learning, 9(1), 78-93.

[61] Beishuizen, J., \& Steffens, K. (2011). A conceptual framework for research on self-regulated learning. In R. Carneiro, P. Lefrere, K. Steffens, K. \& J. Underwood (Eds.), Self-regulated Learning in Technology Enhanced Learning Environments: A European Perspective. Rotterdam: Sense Publishers.

[62] Ahmad, I. I. (2007). Self-regulation of learning and self-motivation and their relationship with the academic achievement of the students of the College of Education (predictive study). Journal of the College of Education, Ein Shams University, 31, part 3, 69-135.

[63] Schunk, D. H. (2005). Commentary on self-regulation in school contexts. Learning and Instruction, 15, 173-177.

[64] Azlina Mohd Kosnin. (2007). Self-regulated learning and academic achievement in Malaysian undergraduates. International Education Journal, 8(1), 221-228.

[65] Al-jarrah A. (2010). The relationship between self-regulated learning and academic achievement among sample of Yarmouk university students. The Jordanian Journal of Educational Sciences, 6(4), 333-348.

[66] Purdie, N., Hattie, J., \& Douglas, G. (1996). Student conceptions of learning and their use of self-regulated learning strategies: A cross-cultural comparison. Journal of Educational Psychology, 88(1), 87-100. doi: 10.1037/0022-0663.88.1.87. 